Article

\title{
Impact of Organic Loading Rate on Performance and Methanogenic Microbial Communities of a Fixed-Bed Anaerobic Reactor at $4{ }^{\circ} \mathrm{C}$
}

\author{
Hongyan Zhao ${ }^{1} \mathbb{D}$, Feifan Yan ${ }^{1}$, Xue $\mathrm{Li}^{2}{ }^{2}$, Renzhe Piao ${ }^{1}$, Weidong Wang ${ }^{3}$ and Zongjun Cui ${ }^{2, *}$ \\ 1 College of Agronomy, Yanbian University, Yanji 133002, China; zhy@ybu.edu.cn (H.Z.); \\ 2018010525@ybu.edu.cn (F.Y.); rzpiao@ybu.edu.cn (R.P.) \\ 2 College of Agronomy and Biotechnology, Center of Biomass Engineering, China Agricultural University, \\ Beijing 100193, China; B20193010033@cau.edu.cn \\ 3 School of Life Science and Technology, Heilongjiang August First Land Reclamation University, \\ Daqing 163000, China; cyywwd@126.com \\ * Correspondence: acuizj@cau.edu.cn; Tel.: +86-10-62731857
}

Received: 26 June 2020; Accepted: 7 September 2020; Published: 16 September 2020

\begin{abstract}
We investigated the feasibility of producing biogas in a fixed-bed anaerobic reactor at $4{ }^{\circ} \mathrm{C}$ with a gradual increase in organic loading rate (OLR). Reactor efficiency was highest when OLR was $4.33 \mathrm{~kg} / \mathrm{m}^{3} \cdot \mathrm{d}$, whereas the reactor acidification occurred when OLR was $4.67 \mathrm{~kg} / \mathrm{m}^{3} \cdot \mathrm{d}$. The values of methane content, biogas production, chemical oxygen demand (COD) removal rate, biogas production rate, acetic acid content, and propionic acid content were $69.3 \%, 5.33 \mathrm{~L}, 59.8 \%$, $1.03 \mathrm{~L} / \mathrm{OLR}, 0.17 \mathrm{~g} / \mathrm{L}$, and $1.15 \mathrm{~g} / \mathrm{L}$, respectively. The $\mathrm{pH}$ was stable and ranged from 7.2 to 6.8 when the reactor was operating at $4{ }^{\circ} \mathrm{C}$ during OLR increase. The $16 \mathrm{~S}$ rRNA gene analysis revealed that the dominant archaea were Methanosaetaceae at $30^{\circ} \mathrm{C}$. At $4{ }^{\circ} \mathrm{C}$, the dominant archaea were Methanomicrobiales, which were more abundant in adhering sludge compared to settled sludge. In conclusion, operating a fixed-bed anaerobic reactor at psychrophilic temperatures is more suitable.
\end{abstract}

Keywords: fixed-bed reactor; organic loading rate; low temperature; anaerobic reactor; methanogens

\section{Introduction}

Anaerobic digestion, an effective treatment for wastewater containing biodegradable organic matter, reduces pollution and produces biogas for use as fuel [1,2]. Many countries have reported using anaerobic digestion for wastewater treatment, including China, the USA, Germany, Austria, Tunisia, Denmark, Italy, Spain, South Africa, and the Netherlands [3-7]. The USA and Germany are capable of producing $100 \%$ of their electricity, whereas Austria is running at an $8 \%$ surplus [4]. However, the capacity for wastewater treatment in China lags behind other countries, especially when it comes to energy recovery [8]. Despite this shortfall, clean energy production via anaerobic digestion of treated wastewater has significant potential in China.

Temperature greatly influences the performance, energy efficiency, and stability of the anaerobic digestion process, especially in cold environments. Most biogas is produced under mesophilic or thermophilic conditions [9-12]. Presently, mesophilic anaerobic digestion has a higher performance and methane content, but lower pathogen sterilization efficiency. Thermophilic anaerobic digestion has a higher organic loading rate (OLR) and an increased ability to kill pathogens; however, the methane content is lower even though energy consumption is higher. The energy input required for anaerobic digestion at psychrophilic temperatures is markedly reduced due to the decreased energy needed for heating the bioreactor; thus, the operating costs for anaerobic digestion at psychrophilic temperatures are considerably reduced $[2,13]$. 
The viability of high-rate anaerobic wastewater treatment for reduced temperature wastewater depends on: (1) the attributes and development of seed material subjected to sub-mesophilic conditions; (2) the exceptionally high sludge retention during elevated hydraulic loading conditions, which allows very little viable biomass to escape from the reactor; (3) good interaction between retained sludge and wastewater to fully utilize the bioreactor capacity; (4) the type of organic pollutants in the wastewater; and (5) the reactor configuration [14].

The feasibility of anaerobic digestion of various wastes with psychrophilic or low-temperature $\left(<20^{\circ} \mathrm{C}\right)$ reactors has been demonstrated in a laboratory setting $[15,16]$. In a study focused on anaerobic degradation of winery wastewater between 4 and $10^{\circ} \mathrm{C}$ with an upflow anaerobic sludge blanket (UASB) type of reactor, effluent chemical oxygen demand (COD) was approximately $0.1 \mathrm{~g} / \mathrm{L}$ [17]. McKeown and colleagues reported that an expanded granular sludge bed-anaerobic filter (EGSB-AF) type of reactor performed stably and efficiently from 4 to $10{ }^{\circ} \mathrm{C}$, with a COD removal rate of $82 \%$, a methane biogas concentration of $>70 \%$, and methane yield $>4$ L.d ${ }^{-1}$ [18]. Molasses is a typical feedstock for fermentation; however, the effluent is hard to treat. As molasses has been a common material for producing ethanol, yeast, amino acids, enzymes, etc., it is necessary to treat molasses-processed wastewater, which has a high COD concentration (50,000-100,000 mg COD/L) and low pH value (4-5) in a timely and effective manner. Additionally, significant emission of wastewater may cause catastrophic harm to the environment. Molasses wastewater contains high levels of organic compounds, cations, and anions, causing operational problems for anaerobic biological treatment. To establish a high organic loading treatment system for industrial molasses wastewater [19,20], we reported the operating parameters and methanogenic community of a fixed-bed reactor at a low temperature of $5-18{ }^{\circ} \mathrm{C}$ in a previous study [21]; however, previous studies have not explored the temperature threshold and the ability of fixed-bed reactors to resist OLR under the temperature threshold. Therefore, the effect of OLR on performance and methane production at $4{ }^{\circ} \mathrm{C}$ for anaerobic digesters has not yet been investigated. Increasing the OLR of the reactor is a necessary step to reduce the anaerobic reactor volume and the cost of engineering [2].

The purpose of this investigation was to determine the effects of increasing substrate OLR on the performance of a fixed-bed anaerobic reactor operated at $4{ }^{\circ} \mathrm{C}$ and establish the maximum OLR shock impact on the reactor performance. Molasses wastewater was treated using a fixed-bed reactor packed with active carbon fiber for biofilm formation. Performance parameters included $\mathrm{pH}$, biogas production, volatile fatty acid (VFA) and methane content, COD removal rate, and the dynamic composition of the methanogenic community.

\section{Methods}

\subsection{Bioreactor}

A laboratory-scale, fixed-bed anaerobic reactor (effective volume, $10 \mathrm{~L}$ ), of the same design as the one described by Zhao [22] was used. The biofilm reactors contained six cylindrical carbon fiber textiles (inner diameter, $5.5 \mathrm{~cm}$; height, $27 \mathrm{~cm}$; thickness, $2 \mathrm{~mm}$ ) joined with stainless steel wire. The bioreactor was positioned in an incubator (Sanyo model MIR 254, Japan) to regulate temperature [21]. Molasses wastewater (MWW) was added to the reactor with a peristaltic pump. Biogas was sampled through a porthole at the top of the reactor, and the biogas volume was determined by water displacement. Effluent (30 to $50 \mathrm{~mL}$ ) was periodically sampled from the reactor. Bioreactor effluent and biogas were collected for the determination of chemical oxygen demand (COD) concentration, VFA content, $\mathrm{pH}$, and methane (CH4) content. The COD concentration was analyzed using a Lovibond water quality monitor (model 99731COD, Germany); VFA concentration was assessed using a high-performance liquid chromatography system (Shimadzu model LC-MS2020, Japan). The Hitachi La ChromC18-AQ $\left(5 \mathrm{~cm}\right.$ ) chromatographic column, column temperature $25{ }^{\circ} \mathrm{C}$, mobile phase was $1 \mathrm{mmol} / \mathrm{L} \mathrm{H}_{2} \mathrm{SO}_{4}$ and $8 \mathrm{mmol} / \mathrm{L} \mathrm{Na}_{2} \mathrm{SO}_{4}$, mobile phase flow rate was $0.6 \mathrm{~mL} / \mathrm{min}$, sample volume was $10 \mu \mathrm{L}$, and the acquisition time was $60 \mathrm{~min}$. The $\mathrm{pH}$ was determined with a $\mathrm{pH}$ meter (Horiba compact model B-212, 
Japan); methane levels were quantified using a biogas analyzer (Landtec, USA).Sampling for the analysis of the reactor operating parameters was carried out every two days.

\subsection{Feeding Solution and Seed Sludge}

Artificial wastewater consisting of molasses (10 L, sag, 70\%; brix, 45\%), Whiskas cat food (800 g, China), and tap water $(90 \mathrm{~L})$ had a COD concentration of $100,000 \mathrm{mg} / \mathrm{L}$. The indicated COD concentrations were attained by diluting the artificial wastewater with water. To ensure that microorganisms received adequate amounts of nitrogen and phosphorus, the ratio of COD:N:P was kept at 300 to 500:5:1. The reactor inoculant consisted of mesophilic ally grown granular sludge (4 L) from a full-scale Coca-Cola production wastewater treatment plant. The total solid (TS) and volatile solid (VS) contents of the inoculated sludge were $33.63 \%$ and $6.16 \%$, respectively.

\subsection{Experimental Protocol}

The reactor ran at a hydraulic retention time (HRT) of six days and an initial operating temperature of $30{ }^{\circ} \mathrm{C}$. MWW was the main carbon source for microbial growth. The trial consisted of two operation stages, which were characterized by changes in temperature or OLR. On day 137 of the trial, the operating temperature was decreased by $2{ }^{\circ} \mathrm{C}$ increments every $2 \mathrm{HRT}$, until the temperature fell to $4{ }^{\circ} \mathrm{C}$, after which the reactor was stably operated for an additional 60 days. The initial OLR was $6.67 \mathrm{~kg} / \mathrm{m}^{3} \cdot \mathrm{d}$. When the operating temperature fell to $4{ }^{\circ} \mathrm{C}$, the OLR fell to $0.67 \mathrm{~kg} / \mathrm{m}^{3} \cdot \mathrm{d}$. To determine the maximum OLR shock impact on reactor performance (Figure 1), the OLR ranged from 0.67 to $4.67 \mathrm{~kg} / \mathrm{m}^{3} \cdot \mathrm{d}$ and increased by $0.33 \mathrm{~kg} / \mathrm{m}^{3} \cdot \mathrm{d}$ with every $2 \mathrm{HRT}$. The $\mathrm{pH}$ of the MWW was maintained at $7.0 \pm 0.2$ by automatic titration with $\mathrm{NaOH}$.

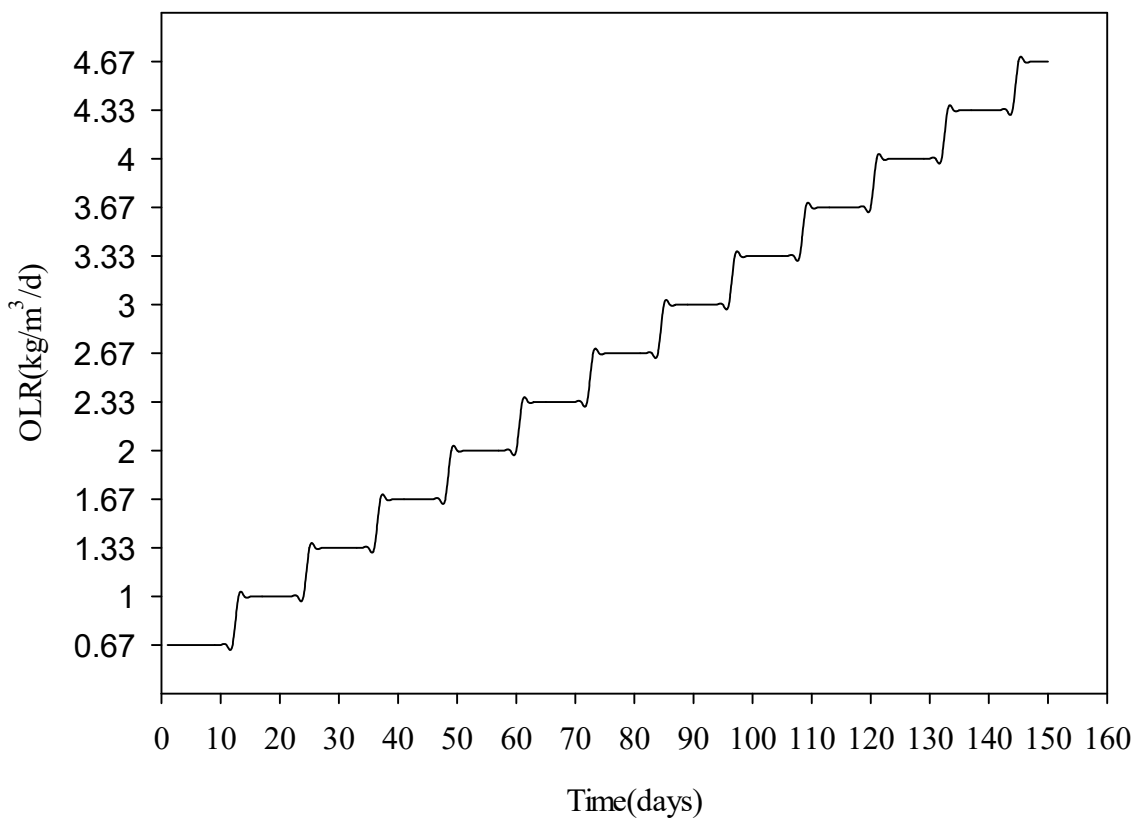

Figure 1. Operating parameters of the fixed-bed reactor at $4{ }^{\circ} \mathrm{C} . \mathrm{OLR}=$ organic loading rate.

\subsection{Quantitative PCR of Methanogens}

Samples of granular sludge from the fixed-bed reactor were collected at $30^{\circ} \mathrm{C}$ and $4{ }^{\circ} \mathrm{C}$. Adherent sludge from the carbon fiber biofilm (approximately $5 \mathrm{~mm}$; designated as adhering sludge) was collected directly from three active carbon fiber sheets $(15 \mathrm{~mm} \times 30 \mathrm{~mm} \times 2 \mathrm{~mm})$ in the reactor. Settled sludge was collected from valves at the bottom of the reactor. After 156 days of operation, collected samples of adhering sludge and settled sludge were centrifuged $(8000 \mathrm{~g}, 10 \mathrm{~min})$ and the supernatants were removed. The resulting samples $(0.3 \mathrm{~g})$ were subsequently used for DNA extraction. The biomass 
amount required for DNA extraction was based on the volatile suspended solids (VSS) concentration. Genomic DNA for the PCR template was extracted with an automated nucleic acid extractor (BioTeke Biotech Co., Ltd., Beijing, China).

Specific primer sets and 5'-nuclease probes for quantitative real-time PCR (Q-PCR) were previously described [23]. The following primers sets were used: Methanobacteriales (MBT; MBT857F, MBT929F, MBT1196R; amplicon size: 343 bp); Methanomicrobiales (MMB; MMB282F, MMB749F, MMB832R; amplicon size: 506 bp); Methanosarcinaceae (MSC; MSC380F, MSC492F, MSC828R; amplicon size: 408 bp); and Methanosaetaceae (MST; MST702F, MST753F, MST862R; amplicon size: 164 bp). TaqMan probes were labeled with a FAM reporter and a BHQ-1 quencher. Reactions were run on an ABI 7500 System (Model 7500, Applied Biosystems, USA). The Q-PCR reaction mix (20 $\mu \mathrm{L})$ consisted of the following ingredients: $2 \times$ TaqMan Universal PCR Master Mix (Applied Biosystems, USA), PCR-grade water; $10 \mu \mathrm{M}$ primers, $1 \mu \mathrm{M}$ TaqMan probe, and template DNA $(1 \mu \mathrm{L})$. The PCR protocol was as follows: denaturation, $10 \mathrm{~min}$ at $94{ }^{\circ} \mathrm{C}$; 40 cycles: $10 \mathrm{~s}$ at $94{ }^{\circ} \mathrm{C}, 30 \mathrm{~s}$ at $60{ }^{\circ} \mathrm{C}\left(63{ }^{\circ} \mathrm{C}\right.$ for the $\mathrm{MMB}$ primer set).

Genomic DNA was extracted from the following archaea species to produce standards for real-time PCR: Methanobacteriales (Methanobrevibacter arboriphilus NBRC101200), Methanomicrobiales (Methanospirillum hungatei NBRC100397), Methanosarcinaceae (Methanosarcina acetivorans NBRC100939), and Methanosaetaceae (Methanosaeta thermophila NCBR101360). Archaea samples were obtained from NITE Biological Research Center (NBRC, Chiba, Japan). PCR (primer sets described above) was used to amplify target rRNA gene sequences from each strain. After purification (TIANgel Midi Purification Kit), the PCR products were inserted into the pGEM-T Easy Vector. Standards for real-time PCR assays were generated by making 10 -fold serial dilutions $\left(10^{2}\right.$ to $10^{9}$ copies per $\left.\mu \mathrm{L}\right)$ of each plasmid. Standard curves were used to estimate $16 \mathrm{~S}$ rRNA gene copy concentrations within a linear range. Granule biomass-based concentrations (copies/g granule VSS) were calculated based on copy number per $\mu \mathrm{L}$ and VSS concentration for each granular sludge sample. Duplicates for each bioreactor DNA sample were analyzed.

\section{Results}

\subsection{Reactor Performance during the Entire Digestion Process}

Biogas production is an indicator of reactor performance. For example, changes in biogas production can reflect altered microbial activity and disorder caused by temperature shock [24]. Biogas production gradually increased with increasing OLR at $4{ }^{\circ} \mathrm{C}$ (Figure $2 \mathrm{a}$ ). When the OLR was $0.67 \mathrm{~kg} / \mathrm{m}^{3} \cdot \mathrm{d}, 1 \mathrm{~kg} / \mathrm{m}^{3} \cdot \mathrm{d}, 1.33 \mathrm{~kg} / \mathrm{m}^{3} \cdot \mathrm{d}, 1.67 \mathrm{~kg} / \mathrm{m}^{3} \cdot \mathrm{d}, 2 \mathrm{~kg} / \mathrm{m}^{3} \cdot \mathrm{d}, 2.33 \mathrm{~kg} / \mathrm{m}^{3} \cdot \mathrm{d}, 2.67 \mathrm{~kg} / \mathrm{m}^{3} \cdot \mathrm{d}, 3 \mathrm{~kg} / \mathrm{m}^{3} \cdot \mathrm{d}$, $3.33 \mathrm{~kg} / \mathrm{m}^{3} \cdot \mathrm{d}, 3.67 \mathrm{~kg} / \mathrm{m}^{3} \cdot \mathrm{d}, 4 \mathrm{~kg} / \mathrm{m}^{3} \cdot \mathrm{d}, 4.33 \mathrm{~kg} / \mathrm{m}^{3} \cdot \mathrm{d}$, and $4.67 \mathrm{~kg} / \mathrm{m}^{3} \cdot \mathrm{d}$, the average biogas production was $0.69 \pm 0.01 \mathrm{~L}, 0.53 \pm 0.01 \mathrm{~L}, 1.02 \pm 0.06 \mathrm{~L}, 1.16 \pm 0.06 \mathrm{~L}, 1.19 \pm 0.06 \mathrm{~L}, 1.26 \pm 0.08 \mathrm{~L}, 1.22 \pm 0.08 \mathrm{~L}$, $1.43 \pm 0.11 \mathrm{~L}, 2.28 \pm 0.21 \mathrm{~L}, 4.12 \pm 0.15 \mathrm{~L}, 3.61 \pm 0.09 \mathrm{~L}, 4.47 \pm 0.10 \mathrm{~L}$, and $2.86 \pm 0.35 \mathrm{~L}$, respectively. When the OLR was between 0.67 and $3 \mathrm{~kg} / \mathrm{m}^{3} \cdot \mathrm{d}$, biogas production ranged from $0.6 \mathrm{~L}$ to $1.6 \mathrm{~L}$. Biogas production dramatically increased to $3.7 \mathrm{~L}$ at an OLR of $3.33 \mathrm{~kg} / \mathrm{m}^{3} \cdot \mathrm{d}$, indicating that the reactor was operating successfully at $4{ }^{\circ} \mathrm{C}$. The highest biogas efficiency was obtained when the OLR was $3.67 \mathrm{~kg} / \mathrm{m}^{3} \cdot \mathrm{d}$, and the biogas production rate was $1.12 \mathrm{~L} / \mathrm{OLR}$. When the OLR was $4.33 \mathrm{~kg} / \mathrm{m}^{3} \cdot \mathrm{d}$, the biogas production rate was $1.03 \mathrm{~L} / \mathrm{OLR}$, indicating that the fixed-bed reactor is stable (Figure $2 \mathrm{~d}$ ). On day 3, biogas production increased to $6.73 \mathrm{~L}$ when the OLR was $4.67 \mathrm{~kg} / \mathrm{m}^{3} \cdot \mathrm{d}$. This increase in biogas production was followed by a rapid decline to $2.34 \mathrm{~L}$ on the fifth day of operation, indicating that the operation of the reactor has been affected when the OLR was 3; however, since the methanogenic microbial communities were suited to the microenvironment in the reactor, biogas production was increased by OLR increase and biogas production tended to gradually stabilize at an OLR of 4.33, and the reactor was soured at an OLR of 4.67. Several previous studies have reported that anaerobic fixed-bed reactors with carbon fiber biofilm have excellent performance when impacted by high organic load rate $[19,21]$. At $4{ }^{\circ} \mathrm{C}, 4.33 \mathrm{~kg} / \mathrm{m}^{3} \cdot \mathrm{d}$ was the optimal OLR. 


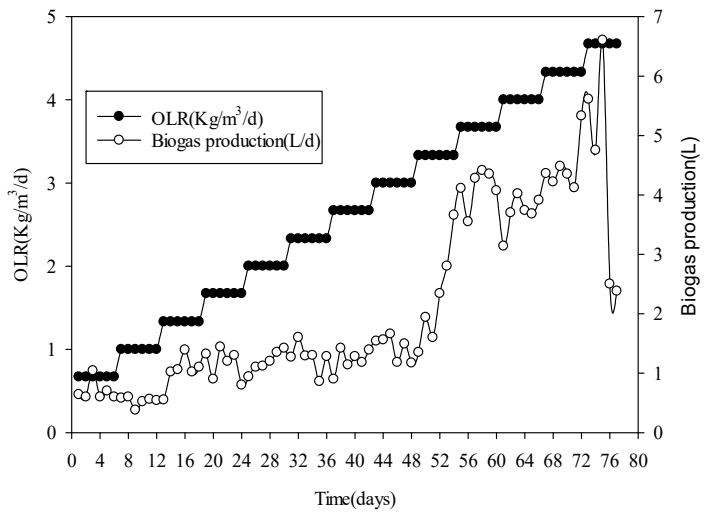

(a)

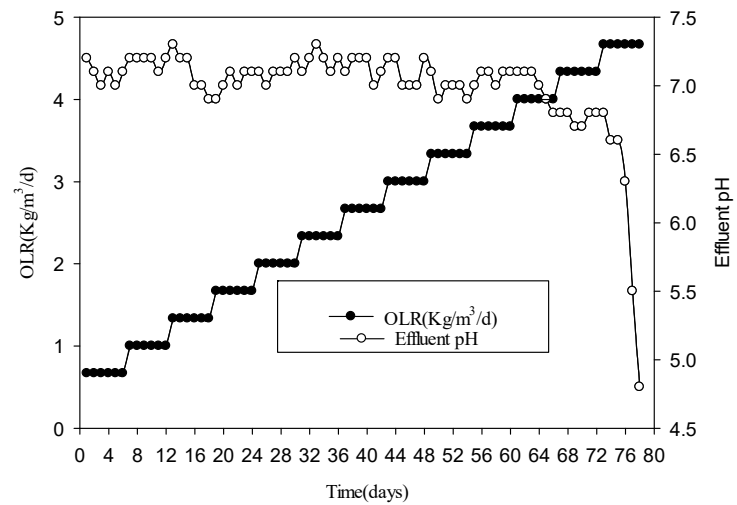

(c)

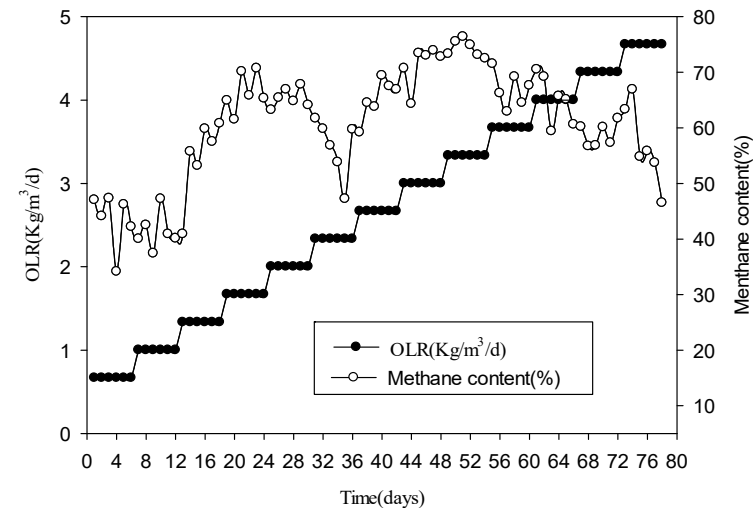

(b)

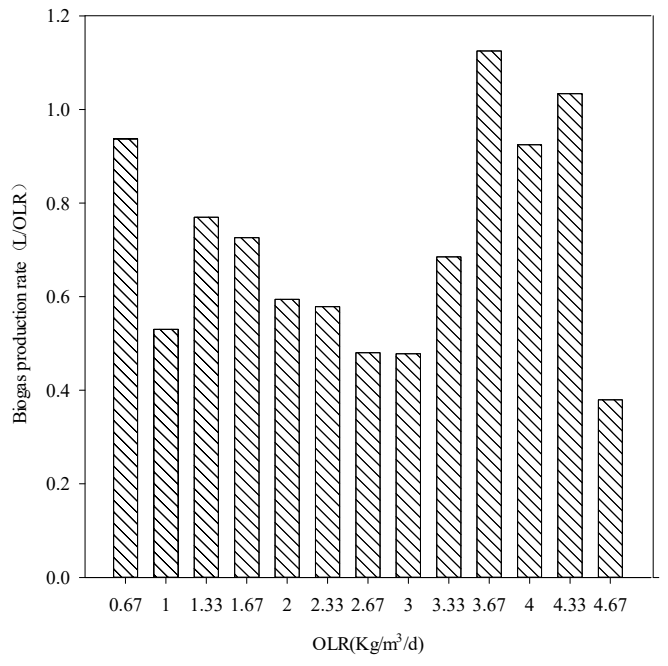

(d)

Figure 2. Reactor performance during the entire digestion process. (a) Biogas production; (b) Methane content; (c) Effluent $\mathrm{pH}$; (d) Biogas production rate.

Figure $2 \mathrm{~b}$ shows changes in the methane content at different OLRs while the operating temperature was $4{ }^{\circ} \mathrm{C}$. At OLRs between $0.67 \mathrm{~kg} / \mathrm{m}^{3} \cdot \mathrm{d}$ and $1.33 \mathrm{~kg} / \mathrm{m}^{3} \cdot \mathrm{d}$, methane content fluctuated between $35.8 \%$ and $57.5 \%$. At an OLR of $1.67 \mathrm{~kg} / \mathrm{m}^{3} \cdot \mathrm{d}$, methane content increased rapidly to $70.7 \%$ and the methane production at this time was $0.6 \mathrm{~L} / \mathrm{d}$. At OLRs between $3.33 \mathrm{~kg} / \mathrm{m}^{3} \cdot \mathrm{d}$ and $4.33 \mathrm{~kg} / \mathrm{m}^{3} \cdot \mathrm{d}$, the methane content was approximately $63.4 \%$ and the methane production at this time was $2.6 \mathrm{~L} / \mathrm{d}$. On operating day 5 , when OLR was $4.67 \mathrm{~kg} / \mathrm{m}^{3} \cdot \mathrm{d}$, the methane content was $46.5 \%$. This indicates that fixed-bed reactors with carbon fiber biofilm and high shock resistance produce more methane at low temperature.

The $\mathrm{pH}$ is an important indicator of operating performance in the anaerobic digestion of wastewater. If the $\mathrm{pH}$ is too low or high, the normal physiological activities of microorganisms in the reactor are inhibited [25]. The optimal $\mathrm{pH}$ range for anaerobic fermentation with methanogens is 6.0 to 8.0 ; thus, the $\mathrm{pH}$ of the wastewater in the anaerobic reactors was maintained within that specified range. At OLRs between $0.67 \mathrm{~kg} / \mathrm{m}^{3} \cdot \mathrm{d}$ and $4.33 \mathrm{~kg} / \mathrm{m}^{3} \cdot \mathrm{d}$, the $\mathrm{pH}$ was stable between 7.2 and 6.8 at $4{ }^{\circ} \mathrm{C}$, indicating that the fixed-bed anaerobic reactor was operating stably under this OLR range. When the OLR was increased to $4.67 \mathrm{~kg} / \mathrm{m}^{3} \cdot \mathrm{d}, \mathrm{pH}$ fell sharply to 5.5 on the fifth day of operation, leading to souring of the reactor. Our results show that the highest OLR was $4.33 \mathrm{~kg} / \mathrm{m}^{3} \cdot \mathrm{d}$ at $4{ }^{\circ} \mathrm{C}$ (Figure $2 \mathrm{c}$ ). 


\subsection{Influent and Effluent COD and COD Removal Rate(a) and VFA Content(b) with OLR throughout the Operation Time}

COD removal is an important indicator of the normal operation of the reactor. The effluent COD rose gradually as the OLR was increased, which suggested that COD accumulated in the digester when the OLR was high $[19,26]$. When the OLR was between 0.67 and $1.33 \mathrm{~kg} / \mathrm{m}^{3} \cdot \mathrm{d}$, a gradual increase in the COD removal rate occurred with increasing OLR at $4{ }^{\circ} \mathrm{C}$. The COD removal rate was $69.5 \%$ at an OLR of $1.33 \mathrm{~kg} / \mathrm{m}^{3} \cdot \mathrm{d}$, for which the influent COD and effluent COD were $4000 \mathrm{mg} / \mathrm{L}$ and $1220 \mathrm{mg} / \mathrm{L}$, respectively. At an OLR of $1.67 \mathrm{~kg} / \mathrm{m}^{3} \cdot \mathrm{d}$, the COD removal rate gradually decreased to $20 \%$, indicating that the OLR was affected by the low temperature. The COD removal rate fluctuated between 35 and $69.5 \%$, with an increase in the OLR. At an OLR of $4.67 \mathrm{~kg} / \mathrm{m}^{3} \cdot \mathrm{d}$, the COD removal rate gradually declined to $10 \%$ on the fifth day of operation. Our results show that the optimal OLR was $4.33 \mathrm{~kg} / \mathrm{m}^{3} \cdot \mathrm{d}$ at $4{ }^{\circ} \mathrm{C}$ (Figure 3a).

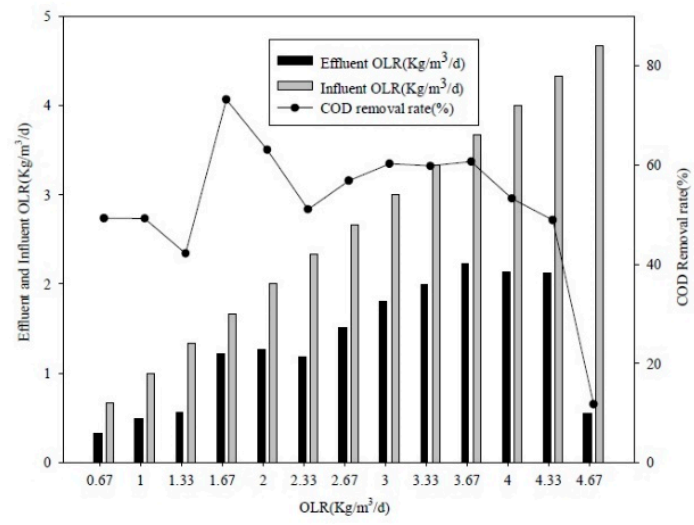

(a)

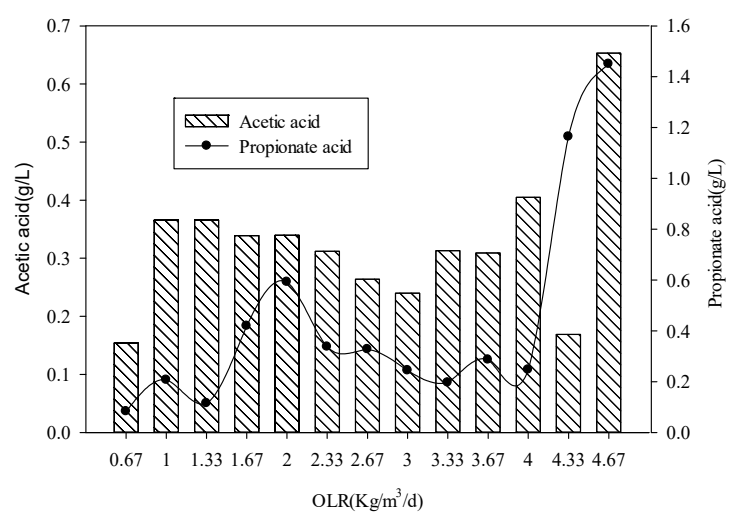

(b)

Figure 3. Influent and effluent chemical oxygen demand (COD) and COD removal rate (a) and volatile fatty acid (VFA) content (b) with OLR throughout the operation time.

The VFA content reflects the operation and organic compound utilization in the anaerobic reactor (Figure $3 b$ ). The acetic acid content increased from $0.15 \mathrm{~g} / \mathrm{L}$ at $0.67 \mathrm{~kg} / \mathrm{m}^{3} \cdot \mathrm{d}$ to $0.37 \mathrm{~g} / \mathrm{L}$ at $1.33 \mathrm{~kg} / \mathrm{m}^{3} \cdot \mathrm{d}$. The propionic acid content was $0.15 \mathrm{~g} / \mathrm{L}$ when the OLR was between $0.67 \mathrm{~kg} / \mathrm{m}^{3} \cdot \mathrm{d}$ and $1.33 \mathrm{~kg} / \mathrm{m}^{3} \cdot \mathrm{d}$. The acetic acid content decreased from $0.34 \mathrm{~g} / \mathrm{L}$ at $1.67 \mathrm{~kg} / \mathrm{m}^{3} \cdot \mathrm{d}$ to $0.24 \mathrm{~g} / \mathrm{L}$ at $3 \mathrm{~kg} / \mathrm{m}^{3} \cdot \mathrm{d}$. The acetic acid and propionic acid contents fluctuated when OLR was between $3.33 \mathrm{~kg} / \mathrm{m}^{3} \cdot \mathrm{d}$ and $4 \mathrm{~kg} / \mathrm{m}^{3} \cdot \mathrm{d}$. When the OLR was $4.33 \mathrm{~kg} / \mathrm{m}^{3} \cdot \mathrm{d}$, the acetic acid content was $0.17 \mathrm{~g} / \mathrm{L}$ and the propionic acid content was $1.15 \mathrm{~g} / \mathrm{L}$. Although the $\mathrm{pH}$ decreased to 6.8, the fixed-bed reactor operated normally for $2 \mathrm{HRT}$. The fixed-bed reactor soured when the OLR reached $4.67 \mathrm{~kg} / \mathrm{m}^{3} \cdot \mathrm{d}$, since acetic acid and propionic acid production exceeded the degradation capacity of the methanogens. A previous report demonstrated that the degradation of methanogenic propionate requires propionate-oxidizing bacteria and methanogenic bacteria. Compared to other VFAs, propionate is highly toxic at low temperatures, if it accumulates [27]. Formic acid and butyric acid were not detected. Our results show that the maximum OLR was $4.33 \mathrm{~kg} / \mathrm{m}^{3} \cdot \mathrm{d}$ at $4{ }^{\circ} \mathrm{C}$.

\subsection{Quantitative PCR of Methanogens}

Quantitative PCR revealed that the methanogenic community composition was altered in both the carbon fiber carrier and settled sludge at $4{ }^{\circ} \mathrm{C}$ (Figure 4). Methanosaetaceae dominated in the seed sludge at $4{ }^{\circ} \mathrm{C}$, and in the carbon fiber carrier and settled sludge at $30^{\circ} \mathrm{C}$, accounting for $95.40 \%, 92.72 \%$, and $97.26 \%$ of the methanogens (sum of all quantified 16s rRNA genes), respectively. These results were consistent with published reports showing a large quantity of Methanosaetaceae in mesophilic anaerobic fermentation of fixed-bed reactors and stable granular anaerobic digesters. 


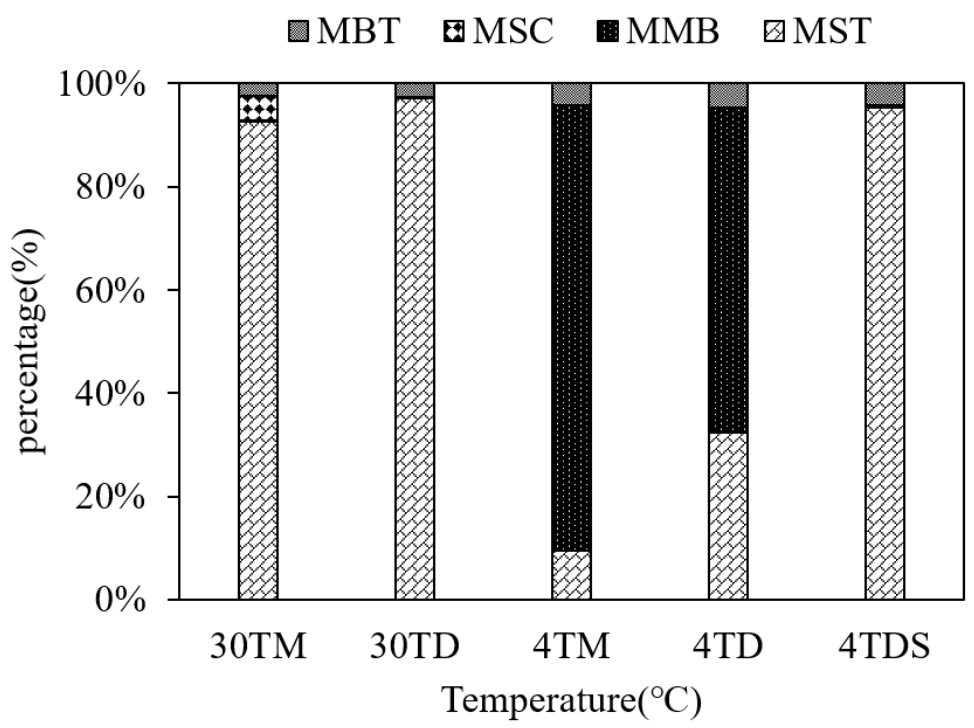

Figure 4. Quantitative PCR of methanogens in adhering sludge and settled sludge. Granular biomass samples from seed inoculum, adherent sludge, and settled sludge were assayed. $\mathbf{S}=$ sample of seed sludge; $\mathbf{T M}=$ adherent sludge; $\mathbf{T D}=$ settled sludge; TDS = sludge sample after reactor souring; $\mathbf{M B T}=$ Methanobacteriales; MSC = Methanosarcinaceae; MMB = Methanomicrobiales; MST = Methanosaetaceae

In both the carbon fiber carrier and settled sludge at $4{ }^{\circ} \mathrm{C}, 16 \mathrm{~S}$ rRNA gene concentrations for Methanomicrobiales were significantly higher than at $30{ }^{\circ} \mathrm{C}$. At $4{ }^{\circ} \mathrm{C}$, the Methanomicrobiales $16 \mathrm{~S}$ rRNA gene concentrations were $99.78 \%$ and $99.91 \%$ more abundant in the carbon fiber carrier and settled sludge, respectively, compared to the concentrations at $30^{\circ} \mathrm{C}$.

Methanomicrobiales 16S rRNA gene concentration was higher in the carbon fiber carrier compared to the settled sludge at $4{ }^{\circ} \mathrm{C}(86.28 \%$ vs. $63.06 \%$ of the methanogenic population). This finding is consistent with published reports showing that Methanomicrobiales tended to adhere to carbon fiber carriers in a fixed-bed reactor, as well as reports demonstrating the dominance of methanogens under psychrophilic conditions $[21,28,29]$.

\section{Discussion}

Many studies on the treatment of wastewater using various bioreactors focused on the low operating temperature of $4{ }^{\circ} \mathrm{C}[17,18,20-33]$. Nevertheless, few reports have discussed the effect of different OLRs on reactor operation in a fixed-bed anaerobic reactor operated at $4{ }^{\circ} \mathrm{C}$. In this study, we treated molasses wastewater with increasing OLRs from $0.67 \mathrm{~kg} / \mathrm{m}^{3} \cdot \mathrm{d}$ to $4.67 \mathrm{~kg} / \mathrm{m}^{3} \cdot \mathrm{d}$ at $4{ }^{\circ} \mathrm{C}$. The maximal treatment OLR of the fixed bed anaerobic reactor were $4.33 \mathrm{~kg} / \mathrm{m}^{3} \cdot \mathrm{d}$ at $4{ }^{\circ} \mathrm{C}$; the COD removal rate was approximately $60 \%$ at this OLR (Figure 3a), demonstrating the improved efficiency of biogas production in a fixed-bed anaerobic reactor compared to other reactors. The treatability of winery wastewater by a UASB reactor was $1.7 \mathrm{~g} / \mathrm{L} \cdot \mathrm{d}$ at $4{ }^{\circ} \mathrm{C}$, with a removal rate of $57 \%$ [17], whereas the treatability of a VFA mixture by an EGSB reactor was $5 \mathrm{~g} / \mathrm{L} \cdot \mathrm{d}$ at $4{ }^{\circ} \mathrm{C}$, with a removal rate $>90 \%$ [33]. Additionally, the treatability of VFA wastewater by an EGSB-AF bioreactor was $3.75 \mathrm{~kg} / \mathrm{m}^{3} \cdot \mathrm{d}$ at $4{ }^{\circ} \mathrm{C}$, with a removal rate $>85 \%$ [18]. Molasses wastewater contains many compounds and a high COD concentration of mineral salts and has a bad smell and dark brown color, and is therefore of serious environmental concern and is hard to treat. There is a high potential for the further utilization of such wastewater. However, to establish a high organic loading treatment system for industrial molasses wastewater, which it produce biogas often most requires need mesophilic or thermophilic conditions, and COD removal rate is approximately $60-80 \%[19,34]$, and we previously reported that the COD removal rate is approximately $50 \%$ at $18{ }^{\circ} \mathrm{C}$ [21]. In summary, the fixed-bed reactor was suitable for 
treating wastewater with a high COD concentration at low temperature and has more advantages compared with other types of reactors.

The major VFAs formed during anaerobic biodegradation of wastewater rare acetic acid, propionic acid, and butyric acid. Propionate accumulation in an anaerobic reactor indicates an unstable anaerobic process; bacteria that degrade propionate are more temperature sensitive than bacteria that degrade acetate, thereby leading to propionate accumulation [35]. Additionally, the accumulation of propionate is a major contributor to reactor souring at psychrophilic temperatures [18]. At an OLR of $4.67 \mathrm{~kg} / \mathrm{m}^{3} \cdot \mathrm{d}$, propionic acid $(1.48 \mathrm{~g} / \mathrm{L})$ accumulated, while $\mathrm{pH}$ fell to 5.5 , and the COD removal rate was approximately $10 \%$, demonstrating that the fixed-bed anaerobic reactor was soured at this OLR.

In this study, the $\mathrm{pH}$ decreased when the OLR was $1.67 \mathrm{~kg} / \mathrm{m}^{3} \cdot \mathrm{d}$. At an OLR of $2 \mathrm{~kg} / \mathrm{m}^{3} \cdot \mathrm{d}$, acetate and propionate contents were $0.346 \mathrm{~g} / \mathrm{L}$ and $0.614 \mathrm{~g} / \mathrm{L}$, respectively. Biogas production and methane content also increased. When the OLR was $3.33 \mathrm{~kg} / \mathrm{m}^{3} \cdot \mathrm{d}$, the acetate content was $0.328 \mathrm{~g} / \mathrm{L}, \mathrm{pH}$ decreased, biogas production increased, and the methane content was $70.7 \%$, this phenomenon shows that the operation of the fixed-bed reactor is impacted under this OLR, and the VFA was accumulation. The significant accumulation of VFAs in the reactor $(>150 \mathrm{mg} / \mathrm{L})$ was the first warning sign that the digester was no longer performing at peak efficiency. Acetate and propionate degradation are susceptible to low temperatures [33]. Due to the low-temperature inhibition of acetogenic bacteria, which resulted in high acetate concentration (300 mg/L), VFA accumulation ultimately led to bioreactor failure, or "souring" [35,36]. Therefore, the highest biogas production efficiency was at an OLR $3.67 \mathrm{~kg} / \mathrm{m}^{3} \cdot \mathrm{d}$, which further confirms that the stable operation of the reactor was at an OLR of $3.33 \mathrm{~kg} / \mathrm{m}^{3} \cdot \mathrm{d}$, and the fixed-bed reactor has a strong shock resistance when operating at $4{ }^{\circ} \mathrm{C}$.

Previous studies have shown that Methanomicrobiales undergo hydrogenotrophic methanogenesis and are critical for low-temperature anaerobic digestion. Methanomicrobiales adhere easily to carbon fiber and fixed-bed reactors use carbon fiber as biofilm carriers [21]. Thus, microbial activity is increased and microbial washout is prevented under psychrophilic conditions. In this study, the concentration of Methanomicrobiales 16S rRNA genes in the fiber carbon and settled sludge increased by approximately 52.23-fold and 185.23 -fold at $4{ }^{\circ} \mathrm{C}$ compared to $30^{\circ} \mathrm{C}$. Therefore, Methanomicrobiales are the dominant methanogens at the low temperature of $4{ }^{\circ} \mathrm{C}$. Previously published reports show that retention of hydrogen is elevated at psychrophilic temperatures because of increased gas solubility. If methanogens are at low temperatures, hydrogen is metabolically and thermodynamically more advantageous than acetate. Therefore, at low temperatures, fixed-bed reactors have better methane production (the methane content was approximately $70 \%$ ) (Figure 2b).

\section{Conclusions}

In this study, the fixed-bed anaerobic reactor was high shock resistance for treating high-concentration organic wastewater at $4{ }^{\circ} \mathrm{C}$. The largest wastewater treatment capacity occurred at $4.33 \mathrm{~kg} / \mathrm{m}^{3} \cdot \mathrm{d}$ OLR. Biogas production peaked when the volume and COD removal rates were $3.7 \mathrm{~L}$ and $69.5 \%$, respectively, at OLRs of $3.33 \mathrm{~kg} / \mathrm{m}^{3} \cdot \mathrm{d} \mathrm{mg} / \mathrm{L}$ and $1.33 \mathrm{~kg} / \mathrm{m}^{3} \cdot \mathrm{d}$, respectively. The highest methane content was $70.7 \%$, and the $\mathrm{pH}$ remained stable between 6.8 and 7.2. Methanomicrobiales, which preferentially adhere to carbon fiber carriers, were the dominant methanogens at $4{ }^{\circ} \mathrm{C}$, and play an important role in anaerobic granular sludge systems.

Author Contributions: Conceptualization, H.Z. and Z.C.; Methodology, X.L. and F.Y.; Software, R.P., X.L. and W.W.; Validation, H.Z., F.Y., X.L., R.P. and Z.C.; Formal Analysis, X.L., F.Y.; Writing-Original Draft Preparation, R.P., X.L. and W.W.; Writing-Review and Editing H.Z. and Z.C.; Supervision, Z.C. All authors have read and agreed to the published version of the manuscript.

Funding: This work was supported by the National Science Foundation of China (No. 51741809), Special Fund for Agro-Scientific Research in the Public Interest (No. 201503137), the National Key Technology Research and Development Program of China (No. 2015BAD21B04), Key projects of Natural Science Foundation of Heilongjiang Province (ZD2018005), and Open Foundation of the Heilongjiang Provincial Key Laboratory of Environmental Microbiology and Recycling of Argo-Waste in Cold Region of China (No. 201711).

Conflicts of Interest: The authors declare no conflict of interest. 


\section{References}

1. Angelidaki, I.; Treu, L.; Tsapekos, P.; Luo, G.; Campanaro, S.; Wenzel, H.; Kougias, P.G. Biogas upgrading and utilization: Current status and perspectives. Biotechnol. Adv. 2018, 36, 452-466.

2. Westerholm, M.; Isaksson, S.; Lindsjö, O.K.; Schnürer, A. Microbial community adaptability to altered temperature conditions determines the potential for process optimisation in biogas production. Appl. Energy 2018, 226, 838-848.

3. Deng, L.; Yang, H.; Liu, G.; Zheng, D.; Chen, Z.; Liu, Y.; Pu, X.; Song, L.; Wang, Z.; Lei, Y. Kinetics of temperature effects and its significance to the heating strategy for anaerobic digestion of swine wastewater. Appl. Energy 2014, 134, 349-355.

4. Smith, K.; Liu, S.; Liu, Y.; Guo, S. Can China reduce energy for water? A review of energy for urban water supply and wastewater treatment and suggestions for change. Renew. Sustain. Energy Rev. 2018, 91, 41-58.

5. Hernandez-Sancho, F.; Molinos-Senante, M.; Sala-Garrido, R. Energy efficiency in Spanish wastewater treatment plants: A non-radial DEA approach. Sci. Total Environ. 2011, 409, 2693-2699.

6. Seier, M.; Schebek, L. Model-based investigation of residual load smoothing through dynamic electricity purchase: The case of wastewater treatment plants in Germany. Appl. Energy 2011, 205, 210-224.

7. Wang, H.; Yang, Y.; Keller, A.A.; Li, X.; Feng, S.; Dong, Y.-N.; Li, F. Comparative analysis of energy intensity and carbon emissions in wastewater treatment in USA, Germany, China and South Africa. Appl. Energy 2016, 184, 873-881. [CrossRef]

8. Zhang, X.; Qi, Y.; Wang, Y.; Wu, J.; Lin, L.; Peng, H.; Qi, H.; Yu, X.; Zhang, Y. Effect of the tap water supply system on China's economy and energy consumption, and its emissionsimpact. Renew. Sustain. Energy Rev. 2016, 64, 660-671.

9. DGhasimi, S.M.; de Kreuk, M.; Maeng, S.K.; Zandvoort, M.H.; van Lier, J.B. High-rate thermophilic bio-methanation of the fine sieved fraction from Dutch municipal raw sewage: Cost-effective potentials for on-site energy recovery. Appl. Energy 2016, 165, 569-582.

10. Fuess, L.T.; Kiyuna, L.S.M.; Ferraz, A.D.N.; Persinoti, G.F.; Squina, F.M.; Garcia, M.L.; Zaiat, M. Thermophilic two-phase anaerobic digestion using an innovative fixed-bed reactor for enhanced organic matter removal and bioenergy recovery from sugarcane vinasse. Appl. Energy 2017, 189, 480-491.

11. Mirmasoumi, S.; Ebrahimi, S.; Saray, R.K. Enhancement of biogas production from sewage sludge in a wastewater treatment plant: Evaluation of pretreatment techniques and co-digestion under mesophilic and thermophilic conditions. Energy 2018, 157, 707-717. [CrossRef]

12. Terboven, C.; Ramm, P.; Herrmann, C. Demand-driven biogas production from sugar beet silage in a novel fixed bed disc reactor under mesophilic and thermophilic conditions. Bioresour. Technol. 2017, 241, 582-592. [CrossRef]

13. Wei, Z.; Cai, X.; Xu, J.; Fang, J.; Liu, H. Psychrophilic anaerobic co-digestion of highland barley straw with two animal manures at high altitude for enhancing biogas production. Energy Convers. Manag. 2014, 88, 40-48. [CrossRef]

14. Mao, C.; Feng, Y.; Wang, X.; Ren, G. Review on research achievements of biogas from anaerobic digestion. Renew. Sustain. Energy Rev. 2015, 45, 540-555. [CrossRef]

15. Crone, B.C.; Garland, J.L.; Sorial, G.A.; Vane, L.M. Significance of dissolved methane in effluents of anaerobically treated low strength wastewater and potential for recovery as an energy product: A review. Water Res. 2016, 104, 520-531. [CrossRef]

16. Smith, A.L.; Skerlos, S.J.; Raskin, L. Anaerobic membrane bioreactor treatment of domestic wastewater at psychrophilic temperatures ranging from $15^{\circ} \mathrm{C}$ to $3{ }^{\circ} \mathrm{C}$. Environ. Sci. Water Res. Technol. 2015, 1, 56-64. [CrossRef]

17. Kalyuzhnyl, S.V.G.; Skylar, M.A.; Kizimenko, V.I.; Shcherbakov, Y.S.; Shcherbakov, S.S. One- and two-stage upflow anaerobic sludge-bed reactor pretreatment of winery wastewater at $4-10^{\circ} \mathrm{C}$. Appl. Biochem. Biotechnol. 2001, 90, 107-124. [CrossRef]

18. McKeown, R.M.; Scully, C.; Mahony, T.; Collins, G.; O'Flaherty, V. Long-term (1,243 days), low-temperature (4-15 degrees), anaerobic biotreatment of acidified wastewaters: Bioprocess performance and physiological characteristics. Water Res. 2009, 43, 1611-1620. [CrossRef] 
19. Meng, X.; Yuan, X.; Ren, X.; Wang, J.; Zhu, X.; Cui, W. Methane production and characteristics of the microbial community in a two-stage fixed-bed anaerobic reactor using molasses. Bioresour. Technol. 2017, 241, 1050-1059. [CrossRef]

20. Li, L.; Yuan, Z.; Sun, Y.; Kong, X.; Dong, P.; Zhang, J. A reused method for molasses-processed wastewater: Effect on silage quality and anaerobic digestion performance of Pennisetum purpereum. Bioresour. Technol. 2017, 241, 1003-1011. [CrossRef]

21. Zhang, D.; Zhu, W.; Tang, C.; Suo, Y.; Gao, L.; Yuan, X.; Wang, X.; Cui, Z. Bioreactor performance and methanogenic population dynamics in a low-temperature (5-18 degrees) anaerobic fixed-bed reactor. Bioresour. Technol. 2012, 104, 136-143. [CrossRef]

22. Zhao, H.; Li, J.; Li, J.; Yuan, X.; Piao, R.; Zhu, W.; Li, H.; Wang, X.; Cui, Z. Organic loading rate shock impact on operation and microbial communities in different anaerobic fixed-bed reactors. Bioresour. Technol. 2013, 140, 211-219. [CrossRef]

23. Yu, Y.; Lee, C.; Kim, J.; Hwang, S. Group-Specific primer and probe sets to detect methanogenic communities using quantitative real-Time polymerase chain reaction. Biotechnol. Bioeng. 2005, 89, 670-679. [CrossRef]

24. Wang, X.; Ye, C.; Zhang, Z.; Guo, Y.; Yang, R.; Chen, S. Effects of temperature shock on $\mathrm{N}_{2} \mathrm{O}$ emissions from denitrifying activated sludge and associated active bacteria. Bioresour. Technol. 2018, 249, 605-611. [CrossRef]

25. Zhou, J.; Zhang, R.; Liu, F.; Yong, X.; Wu, X.; Zheng, T.; Jiang, M.; Jia, H. Biogas production and microbial community shift through neutral $\mathrm{pH}$ control during the anaerobic digestion of pig manure. Bioresour. Technol. 2016, 217, 44-49. [CrossRef]

26. Wu, S.; Dang, Y.; Liu, B.Q.Z.; Sun, D. Effective treatment of fermentation wastewater containing high concentration of sulfate by two-stage expanded granular sludge bed reactors. Int. Biodeterior. Biodegrad. 2015, 104, 15-20. [CrossRef]

27. Dhaked, C.K.W.R.K.; Alam, S.I.; Kamboj, D.V.; Singh, L. Effect of propionate toxicity on methanogenesis of night soil at psychrophilic temperature. Bioresour. Technol. 2003, 87, 299-303. [CrossRef]

28. Zhang, D.; Li, J.; Guo, P.; Li, P.; Suo, Y.; Wang, X.; Cui, Z. Dynamic transition of microbial communities in response to acidification in fixed-bed anaerobic baffled reactors (FABR) of two different flow directions. Bioresour. Technol. 2011, 102, 4703-4711. [CrossRef]

29. Siggins, A.; Enright, A.M.; O'Flaherty, V. Low-temperature (7 degrees) anaerobic treatment of a trichloroethylene-contaminated wastewater: Microbial community development. Water Res. 2011, 45, 4035-4046. [CrossRef]

30. Scully, C.; Collins, G.; O’Flaherty, V. Anaerobic biological treatment of phenol at 9.5-15 degrees in an expanded granular sludge bed (EGSB)-based bioreactor. Water Res. 2006, 40, 3737-3744. [CrossRef]

31. Angenent, L.T.; Banik, G.C.; Sung, S. Anaerobic migrating blanket reactor treatment of low-strength wastewater at low temperatures. Water Environ. Res. 2001, 1, 567-574. [CrossRef]

32. Lettinga, G.; Rebac, S.; Zeeman, G. Challenge of psychrophilic anaerobic wastewater treatment. Trends Biotechnol. 2001, 19, 363-370. [CrossRef]

33. Lettinga, G.; Rebac, S.; Parshina, S.; Nozhevnikova, A.; van Lier, J.B.; Stams, A.J.M. High-rate anaerobic treatment of wastewater at low temperatures. Appl. Environ. Microbiol. 1999, 65, 1696-1702. [CrossRef]

34. Kuroda, K.; Chosei, T.; Nakahara, N.; Hatamoto, M.; Wakabayashi, T.; Kawai, T.; Araki, N.; Syutsubo, K.; Yamaguchi, T. High organic loading treatment for industrial molasses wastewater and microbial community shifts corresponding to system development. Bioresour. Technol. 2015, 196, 225-234. [CrossRef] [PubMed]

35. Langenhoff, A.A.; Stuckey, D.C. Treatment of dilute wastewater using an anaerobic baffled reactor effect of low temperature. Water Res. 2000, 34, 3867-3875. [CrossRef]

36. Connaughton, S.; Collins, G.; O'Flaherty, V. Development of microbial community structure and activity in a high-rate anaerobic bioreactor at $18^{\circ} \mathrm{C}$. Water Res. 2006, 40, 1009-1017. [CrossRef]

(C) 2020 by the authors. Licensee MDPI, Basel, Switzerland. This article is an open access article distributed under the terms and conditions of the Creative Commons Attribution (CC BY) license (http://creativecommons.org/licenses/by/4.0/). 